\title{
TAX CONSEQUENCES OF COMPENSATION POLICIES
}

\author{
VERN KRISHNA*
}

The importance of compensation policies and reward structures bears a direct relationship to the burden imposed by the incidence of income taxation. When, as at the present time, inflation and substantial tax rates erode an individual's earning, indirect compensation and devices to reduce income taxation assume greater significance to all wage earners. In this paper Mr. Krishna examines several alternative schemes to direct remuneration which have the effect of minimizing current taxation and deferring the incidence of taxes to some future time period, thereby mitigating against the ultimate erosion of earnings. The emphasis of the paper is on the deferral of tax and indirect compensation schemes, and is premised on the principle that deferral is tantamount to tax saving.

\section{INTRODUCTION}

The issue of compensation is as old as the need of man for reward in return for his services. However, whereas at one time, the question of reward was directly related to the provision of services, since 1917 the relationship has been influenced by an intervening variable imposed by a third party to the relationshp viz. income tax levied by the Federal Government of Canada. Given this intervening variable, employees and tax planners have become increasingly aware of the need to maximize the reward-service interaction. The most obvious and accepted medium of reward has traditionally been and remains to this day the payment of a cash remuneration. There remain, however, other forms of compensation which assume increasing importance in direct proportion to the burden imposed by taxation. The purpose of this paper is to evaluate in some depth these alternative media for remuneration.

In this regard, it is perhaps tautological to suggest that the key to understanding employee behaviour is to understand their perception of the situation they are in. The motivational consequences will depend in large measure on the nature of the employer-employee relationship, the employee's tax position and the employer's incentive to provide a reward, direct or indirect. Given these attributes, one may examine the investment decision of the employee and employer as one that primarily weights risk against return and involves in its analysis factors of time, diversification and the ultimate objective of the investment of time.

Doubtless, the Utopia of both the employee and the employer would be the non-existence of any tax; at least in the short run. Given reality, however, avoiding tax altogether, it seems, is a thing of the past and one strives only to minimize its incidence. The decision, therefore, must consider the following aspects of tax planning:

(i) conversion,

(ii) split income,

(iii) income averaging,

(iv) deferment.

This paper discusses several forms of compensation as an alternative to immediate cash rewards, which maximize the concept of deferred taxation. The advantages of tax deferral are threefold:

(i) it permits the postponement of tax effects until such a future 
period when one may reasonably be expected to be placed in a lower marginal tax category;

(ii) it provides for the utilization of funds which would otherwise be expended in the payment of taxes. If such funds are invested and compounded, the tax effects of the original levy may, over an extended period of time, be totally negated;

(iii) it permits the payment of one's tax burden in inflated dollars which deprive the taxpayer of a lesser amount of real purchasing power, than if paid immediately.

If deferment, then, is considered to be a desirable objective, consideration may be given to the vehicles of deferment discussed in the pages following.

\section{General}

\section{REGISTERED PENSION PLANS}

Indirectly, but significantly, the Federal Government has played an important role in determining the structure and behaviour of pension plans through welfare legislation: e.g. Canada Pension Plan, Old Age Security and, predominantly, the Income Tax Act. The primary effect of the statutory provisions in the I.T.A. is to stimulate a measure of thrift on the part of the employee. This is achieved by permitting a deduction to the employee and the employer, as a consequence of which, tax which would otherwise be payable on these contributions, is effectively deferred until such future time when the proceeds are received as a retirement benefit. Through this mechanism current income is reduced, and taxes deferred to a time when marginal rates of tax will usually be lower. That deferment is an effective means of tax reduction, may be seen by considering the present value of a dollar to be received in some future time period. The present value of $\$ 1$ given a $10 \%$ rate of interest is $\$ 0.14$ in 20 years, and at a $20 \%$ rate of interest is nil in 30 years.

To obtain the maximum benefits of the various provisions of the I.T.A., it is essential to have the plan registered. In this regard, there are no statutory rules touching on the acceptability of pension plans. Registration is within the discretion of the Minister of National Revenue, and hence it is of some considerable importance to ensure compliance with Departmental provisions and guidelines. One of the essential features of such plans, for the purposes of registration, is that the contribution of the employer must be irrevocably parted with and that under no circumstances may the contribution revert back to the employer. Where an employee leaves the employer, or if the contribution is not fully utilized for some other reason, then the funds should be used to reduce other payments and premiums.

There are, in essence, two variations on the same theme in respect of a pension plans:

(i) Contract Purchase Plans are those under which pension or annuity contracts are purchased to provide a pension commencing at some specified time. There should be some evidence supported by appropriate documentation, that the pension plan is for the benefit of employees and is irrevocable. Further, the beneficiaries are not permitted to borrow upon the plan, as this would defeat the purpose of the plan, which is to provide a pension.

(ii) Pension Trust Plans require a deed, setting out the details of the plan in accordance with the requirements stipulated in (i) above. 
In summary, deferred statutory plans offer the following common characteristics:

(i) contributions to the registered pension plan are deductible from income by both the employee and the employer within prescribed limits;

(ii) the benefits of such plans are taxable as income upon extraction from the plan, presumably at the then expected lower marginal rates upon retirement; and

(iii) the registered pension plan is itself exempt from taxation during the tenure of the plan.

\section{Technical Considerations}

Registered Pension Plan is defined in s. 248(1) I.T.A. as "... an employee's superannuation or pension fund or plan accepted by the Minister for registration...for the taxation year under consideration ...." [Emphasis added.] The wording of this section would indicate that an annual registration is required. In practice, however, an initial registration is sufficient to qualify in subsequent years. It is important to observe, however, that the Minister is not estopped from disallowing a deduction for a particular year, merely on the premise that the deduction may have been permitted in prior years. Hence, in Patons $\&$ Baldwins Ltd. v. $M N R^{1}$ the appellant company had made payments into its pension plan for 1961,1962 and 1963 and deducted these payments from its income for the years concerned. The deductions being disallowed on the basis that the plan was unregistered, the appellant company argued that the deduction had been permitted in years prior to 1961. The Board held that what the Department may have done in prior years was not binding on the Crown. The Department has indicated however, that as a matter of practice, termination of registration will not be retroactive to prior years in the absence of fraud or misrepresentation. ${ }^{2}$

(i) Nature of Plan: Paragraph 6(a) of I.C. No. 72-13, defines an employee's pension plan as a definite arrangement established as a continuing policy by an employer or group of employers or by a union in conjunction with such employers, the terms and conditions of which must be set out in writing. The purpose of such plans is to provide pensions to employees and cannot be used merely as a scheme to divert profits. In addition, the benefits provided must be for the employees, their beneficiaries or their estate. The pension must be provided by the employer as consideration for services rendered by the employee, and the plan may be either contributory or non-contributory in its funding.

(ii) Funding: The pension plan must be funded through certain specified media. These include life insurance businesses, trust companies, corporate pension societies, Provincial or Federal Governments.

(iii) Institution of Plans: Any employer may institute a plan for his employees. However, employees do not include self-employed persons, partners, proprietors, nor the spouses of any of the above. Further, the plan cannot be for the "primary" benefit of significant shareholders or their parents, children or spouses. These

1 (1969) D.T.C. 189.

2 I.C. No. 72-13 (May 31, 1972) para. 5. 
provisions were introduced to prevent the abuse of such plans from becoming "Top Hat" Pension Plans. For this purpose a "significant shareholder" is one who, alone or in combination with a parent, spouse or child owns, controls or has a beneficial interest, directly or indirectly, in shares that represent $10 \%$ or more of the voting power attached to all shares of a company that is participating in the plan. However, this rule may be waived if the corporation is not controlled by the significant shareholders who are members and persons related to them. ${ }^{3}$ What is or is not "primarily for" the benefit of shareholders is a question of fact in each case. The Departmental guidelines indicate, however, that a plan will be considered to be "primarily for" the benefit of such shareholders if the present value of the benefits accrued to or purchased for significant shareholders and their spouses, children and parents is greater than the present value of the benefits accrued to the other employees of the company.

(iv) Investments: The types of investments that the plan is permitted to make are regulated by the Canadian and British Insurance Companies Act, ${ }^{4}$ specifically s.63 ss. (1), (2), (5), (6), (10). The key element to this section is that the type of investments as contemplated are generally of a long term nature, and the concern is with quality and, to some extent diversification. It should be observed that there is little concern over the size of particular investments as it relates to the company securities purchased. In this regard there is a considerable measure of discretion.

(v) Administrative Costs: The employer's deductible portion is limited by s.20(1)(q) I.T.A. and 8.2700 of the Regulations. However, these provisions apply to contributions paid into the fund. As such, there is no limit on the deductibility of administrative costs as business expenses so long as they are reasonable pursuant to 8.67 .5

(vi) Maximum Benefits: Plans providing pension benefits on a definite benefit basis and plans funded in whole or in part under $\mathbf{s . 2 0}(1)(\mathrm{s})$ or $\mathbf{s . 2 0}(1)(\mathrm{r})$ of the I.T.A. must specifically prohibit the maximum annual pension at retirement, termination of employment or termination of the plan, from exceeding the lesser of:

(a) $\$ 1,143$ times the number of years of service not exceeding 35 , or

(b) an amount that is the product of

(i) $2 \%$ per year of service not exceeding 35 years, and

(ii) the average of the best five years of remuneration paid to the employee by the employer, except that the above prohibition will not apply to annual pensions of $\$ 120$ or less per year of service nor will it apply to the portion of the annual pension derived from an employee's voluntary contributions an account of current service. ${ }^{6}$

An employer may have more than one plan, with varying rates of contributions and benefits. Thus, there may be one plan for salaried per-

${ }^{3}$ Id. para. 8(d).

- R.S.C. 1952, c. 31 as amended.

5 I.T.-105, (May 30, 1973).

- Supra, n. 2, para. 9 (g). 
sons and another for hourly rated personnel. At the same time it may be possible to arrange a greater rate of contribution for executives, thereby providing a considerable degree of flexibility to the employer.

\section{Employee Contributions}

There is a limit to the deductibility of contributions made by an employee in respect of each pension plan in respect of current services and past services while not a contributor.

(i) Current: By virtue of $s .8(1)(\mathrm{m})$ the deduction is only permitted for the computation of income from an office or employment. Any contribution to an unregistered plan will not be deductible. Further, of interest to commuting Canadian residents residing in border towns, is the interpretation that contributions to plans establised by U.S. employers are not deductible, where such plans have not received Canadian registration. Hence, in Earl v. $M N R,{ }^{7}$ the appellant resided in Ontario and commuted daily to his employment in the State of New York. He sought to deduct contributions made to his U.S. employer's pension plan, and was unsuccessful due to the absence of Canadian registration of the plan. Again in Ledwidge v. $M N R{ }^{8}$ the appellant who had formerly been a citizen of France, sought to deduct contributions made to the French National Fund. The deduction was rejected on the basis that the fund was not a registered pension plan within the context of the I.T.A.

By virtue of s.8(6) I.T.A., the deduction for current services is limited to $\$ 2,500$ per annum, and where the employee is contributing to more than one plan, his overall limit remains at $\$ 2$,500 per year. If this latter situation prevails, the employee is required to designate his contribution limit for each plan. Further, the contribution must be withheld from remuneration or paid as part of his union dues. In this regard, it is imperative to observe, that sums paid in excess of the contribution limit for current services cannot be carried over to the following year. For example, where the taxpayer contributes a total of $\$ 4,000$ to two plans as follows:

Contribution for the Year

$$
\begin{array}{crr}
P L A N ~ 1 & P L A N 2 & \text { TOTAL } \\
\$ 1,500 & \$ 2,500 & \$ 4,000
\end{array}
$$

Designated contribution

Limit per s.8(6)

$1,500 \quad 1,000 \quad 2,500$

The $\$ 1,500$ excess contribution to Plan 2 will not be deductible.

(ii) Past Services: The contribution limit for past services is restricted to $\$ 2,500$ per year in addition to the current service deduction, by virtue of $\mathrm{s.8(1)(m)(ii).} \mathrm{However,} \mathrm{the} \mathrm{deduction} \mathrm{can-}$ not exceed in total:

( $\left.\begin{array}{l}\text { Number of Years } \\ \text { While Not Contributor }\end{array} \quad \mathrm{X} \begin{array}{l}\text { Contribution } \\ \text { Limit }\end{array}\right) \begin{aligned} & \text { Amounts deducted } \\ & \text { - under this provision } \\ & \text { in previous years. }\end{aligned}$

Several points may be observed in the context of this discussion:

(a) Although prior to 1972 the contribution limit was $\$ 1,500$ per year, a taxpayer may take advantage of the provision and contribute $\$ 2,500$ retroactively per year for past services.

7 (1966) 40 Tax A.B.C. 329.

(1971) Tax A.B.C. 254. 
(b) Section $8(1)(\mathrm{m})(i i)$ does not require the amounts deducted to be withheld from salary as in the case of current service contributions under s.8(1)(m)(i). Hence, the funds may be usefully invested in the interim period.

(c) While past service contributions may apply to a number of plans, the contribution limit must be designated in accordance with s.8(6).

(d) When the contributions in respect of past services exceed the allowable amounts, the excess may be carried forward and deducted in subsequent years by virtue of s.8(8). This is illustrated in the example below:

\begin{tabular}{|c|c|c|c|}
\hline $\begin{array}{l}\text { Designated Contribution } \\
\text { Limit per s.8(6) } \\
\text { No. of Eligible Past Years } \\
\text { Maximum Deduction } \\
\text { Amount Deducted in Prior Years }\end{array}$ & $\begin{array}{r}P L A N 1 \\
\$ 1500 \\
8 \\
12,000 \\
10,000 \\
\end{array}$ & $\begin{array}{r}P L A N 2 \\
\$ 1000 \\
2 \\
2000 \\
1500 \\
\end{array}$ & $\begin{array}{r}\text { TOTAL } \\
\$ 2500 \\
14,000 \\
11,500 \\
\end{array}$ \\
\hline $\begin{array}{l}\text { Carryover to Current Year } \\
\text { Amount Paid in Current Year }\end{array}$ & $\begin{array}{r}\$ 2000 \\
1500\end{array}$ & $\begin{array}{r}500 \\
1000\end{array}$ & $\begin{array}{r}\$ 2500 \\
2500\end{array}$ \\
\hline $\begin{array}{l}\text { Amount Not Deductible } \\
\text { Carryover to Later Years }\end{array}$ & $\$ 5 \overline{0}$ & $\$ 500$ & $\begin{array}{ll}\$ & 500 \\
\$ & 500\end{array}$ \\
\hline
\end{tabular}

(e) Where an employee, having contributed in the past to his company's pension plan, is later permitted to increase his contributions, a deduction may be made under $8.8(1)(\mathrm{m})(\mathrm{iii})$ in respect of past services. However, no deduction may be made under $\mathrm{s.8}(1)(\mathrm{m})(\mathrm{iii})$ unless the amount deducted under $\mathrm{s.8}(1)(\mathrm{m})(\mathrm{i})$ and $\mathrm{s.8}(1)(\mathrm{m})(\mathrm{ii})$ is less than $\$ 2,500$. Again, there is a carryover provision in $8.8(8)$.

\section{Employer Contributions}

(i) Current: By 8.20(1)(q)(i) the employer may deduct up to $\$ 2,500$ per employee, where the contribution is identifiable for particular employees. Where, however, the employees on whose behalf the contributions are made are not identifiable, the amount deductible cannot exceed $\$ 2,500$ times the number of employees covered by the plan. Thus, assuming a total payroll cost of $\$ 500,000$ and an employer's current contribution of $\$ 30,000$, the contribution ratio is $6 \%$. Since the contribution on a salary of $\$ 41,666$ at $6 \%=\$ 2,500$, any amount of salary in excess of $\$ 41,666$ would cause a disallowance as an expense to the employer of its pension payment to the extent of $6 \%$ of such excess. Hence, on a salary of $\$ 50,000$ an amount of $\$ 500$ would be disallowed: (6\% X $\$ 50,000-\$ 2,500)=\$ 500$.

The payments into the plan may be made within 120 days after the close of the taxation year, thereby permitting employers to base their contributions on the profits of the company. Where, however, the pension is financed by terminal funding i.e. lump sum contribution made by a company upon retirement of the employee, the contribution is deductible under $8.20(1)(r)$ within 60 days of the end of the tax year. It should be observed that the employee does not include such benefit in his income, even where the employer has made excessive payments to the plan.- 
s.(6)(1)(a). Rather, only payments received by the employee are taxable under 8.56(1)(a).

(ii) Past Service: By virtue of $8.20(1)(8)$ an employer may make a contribution for past services. However, the requirements are rather stringent, as indicated below:

(a) The resources of the fund must have required the augmentation of the plan by way of additional contribution. This condition was strictly interpreted by the Supreme Court of Canada in Inland Industries Ltd. v. MNR. ${ }^{9}$

(b) There must be a recommendation from a qualified actuary.

(c) The recommendation in (b) above must be approved by the MNR on the advice of the Superintendent of Insurance. Due to the growth of "Top Hat" funds which were designed to benefit shareholders rather than employees the MNR has disallowed previously approved deductions. In Susan Hosiery Ltd. v. $M N R,{ }^{10}$ the appellant company devised a circuitous method of revolving funds. The company employed 150 employees, but set up its plan for 4 shareholders. An actuarial deficit of $\$ 217,000$ for past services having been confirmed, the company borrowed money from the bank to pay the trust company. The plan was then liquidated immediately thereafter, the sum being paid to the shareholders, who in turn paid off their outstanding loans to the company. The Exchequer Court dismissed the appeal on the grounds that there was never any intention to implement a bona fide pension plan and what was done, constituted in essence, a sham.

(d) Where the $M N R$ has given prior approval to past service contributions, he may, nevertheless, withdraw the registration of a pension plan where he was unaware of the true character of the transactions. Thus, in West Hill Redevelopment Ltd. v. $M N R,{ }^{11}$ the company paid $\$ 195,244$ to two controlling shareholders as trustees under the pension plan. The trustees then paid themselves as beneficiaries, who then issued their own cheques in favour of a deferred profit sharing plan, which then invested the funds in preference shares of the appellant company. The Exchequer Court, in giving due regard to substance over form, held that the plan was a mere masquerade, and there was as a consequence no true pension plan in existence.

(e) As with all other transactions the $M N R$ has considerable power under s.245(1). This power was applied to the area of past service deductions in The Cattermok-Tretheway Contractors $L t d$. v. $M N R,{ }^{12}$ where the appellant set up an employee's pension plan for the benefit of two controlling shareholders and made payments in respect of past services for $\$ 127,679$. The money travelled in a circle, arriving back into the appellant company. The deduction was disllowed as an artificial transaction. In coming to its decision the Exchequer Court were greatly assisted by a letter on file from the

\footnotetext{
9 [1972] C.T.C. 27.

${ }^{10}$ [1969] C.T.C. 533.

" [1969] C.T.C. 581.

${ }^{12}$ [1970] C.T.C. 619.
} 
appellant's accounting firm which commenced with the words "... [F] current income taxes ..."!!

While the new provisions prohibiting "Top Hat" funds may have blocked the above cited illustrations of "revolving funds", the stringency of these cases in regard to past service contributions should not be overlooked nor minimized. The amount of past service contribution may not exceed the proportion of the number of years of past service that is the lesser of:

(i) the total number of years of past service and potential future service to normal retirement age, or

(ii) the total number of years of past service and potential future service until a total pension of $70 \%$ is accrued e.g. 35 years for $2 \%$ per year accrual or 40 years for $13 \% 4$ per year accrual.

Although the benefit is eventually taxed in the hands of the recipient of the pension, a susbstantial advantage is obtained in that it defers taxation and usually involves a lower marginal tax rate upon retirement. Table A provides an illustration of the savings to be achieved.

TABLE A

Cash available for investment

$\$ 100,000$

Profit of Corporation

Corporate Tax Payable:

First $\$ 50,000$ using $8.125(1)$

Next $\$ 70,000 @ 50 \%$

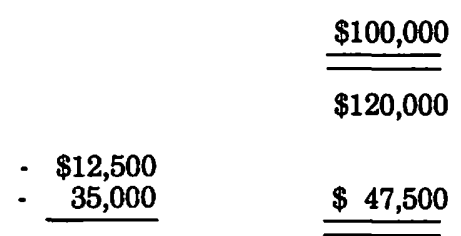

Assume an executive, age 50, requires a pension at age 65 guaranteed for 10 years of approximately $\$ 16,500$.

Lump sum required to fund

Corporate Taxable Income after lump sum payment

$\$ 100,000$

Corporate Tax Payable using s.125(1)

$\$ 20,000$

Amount of Tax Deferred

$\$ 5000$

$\$ 42,500$

Thus, of the $\$ 100,000$ contributed the net cost was $\$ 57,500$.

The amount of the tax deferred may be increased by spreading the payment over two years as shown in Table $B$, which assumes that the corporation has a taxable income of $\$ 100,000$ in the second year. 
TABLE B

Tax Payable Without Deferral

Corporate Taxable Income

Year 1

Year 2

Corporate Tax Payable:

$\$ 120,000$

$\$ 100,000$

Per Table A

On First $\$ 50,000$ Using

s.125(1)

On Next $\$ 50,000$ @ 50\%

25,000

$\$ 37,500$

Total Tax Paid

$=\$ 85,000$

Tax Payable With Deferral

Corporate Taxable Income

Lump Sum Contribution

Net Taxable Income

Corporate Tax Payable:

On First $\$ 50,000$ Using

8.125(1)

On Next $\$ 20,000$

\begin{tabular}{rr}
$\$ 120,000$ & $\begin{array}{r}\$ 100,000 \\
50,000\end{array}$ \\
\hline$\$ 70,000$ & $\quad \begin{array}{r}50,000 \\
\$ 50,000\end{array}$
\end{tabular}

\begin{tabular}{|c|c|}
\hline $\begin{array}{r}12,500 \\
10,000\end{array}$ & $\$ 12,500$ \\
\hline$\$ 22,500$ & $\$ 12,500$ \\
\hline
\end{tabular}

TOTAL TAX PAID

NET TAX DEFERRAL

The deferred tax of $\$ 50,000$ accumulating at $7 \%$ in the pension plan and exempt from tax would provide $\$ 137,952$ in 15 years. If withdrawn at age 65 and subject to a $50 \%$ marginal tax rate, the executive would receive $\$ 68,976$ after tax. Thus, the $\$ 50,000$ corporate tax deferred is transformed into a permanent saving, and creates an additional $\$ 18,976$ post tax income for the executive.

\section{Taxation of the Fund}

A trust or a corporation that is established or incorporated solely in connection with, or for the administration of a registered pension fund or plan is exempt from income tax by s.149(1)(0). Notwithstanding this tax exemption, however, there are punitive taxes imposed on the fund when the fund holds "foreign property" in excess of $10 \%$ of the cost of all its property by virtue of s.206(1). Thus, a trust or corporation administering such a plan must compute the cost of its total property and "foreign property" on a monthly basis. Where the cost of "foreign property" exceeds $10 \%$ of the total cost of all property, a tax of $1 \%$ is imposed for that month as seen below:

Cost of all property

Cost of "foreign property"

Excess of F.P. over $10 \%$

Tax Payable - 8.206(1)

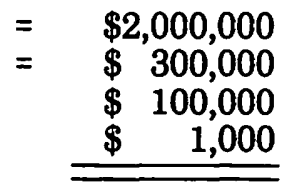

Where, however, the "foreign property" was acquired prior to June 19, 1971 , that amount is not taken into account in the computation of the special tax. Hence, if $\$ 250,000$ of the $\$ 300,000$ "foreign property" in the 
illustration above was acquired prior to June 19,1971 and $\$ 50,000$ was acquired subsequent to that date, the special tax would be $\$ 500$ instead of $\$ 1,000$. "Foreign property" is defined in $8.206(2)$ and further clarified in Part L of the Regulations. The trust or corporation administering the plan must file within 90 days of the end of the taxation year a computation of the tax payable for each month of the year. Such information is required to be filed without notice or demand and whether or not any tax is payable under s.207(1). Failure to file the prescribed information renders the trustee personally liable under s.207(2), although he may recover from the trust.

\section{Benefits}

By virtue of $8.56(1)(a)(i)$, payments out of the pension fund are taxable when received by the taxpayer. Hence, the tax is imposed on the "cash" basis rather than on an accrual basis. From a planning viewpoint it is important to note that pension benefits are taxable whether or not they are paid out of a registered pension plan. In this regard, registration only affects the deductibility of contributions, and not the taxability of benefits when received. Hence, it becomes imperative that excessive payments into the plan should be avoided in order to prevent double taxation. An illustration of double taxation may be seen in the Estate of G.W. Rea v. $M N R .^{13}$ In that case the taxpayer, who was a former university professor, had made both deductible contributions as well as substantial additional non-deductible contributions in excess of the limits previously discussed. Upon receiving his pension benefits he was taxed on the entire amount received.

In addition, U.S. citizens moving to Canada upon retirement should be extremely careful in planning their retirement. Under U.S. law certain pensions e.g. under the U.S. Civil Service Retirement Annuity, are exempt from tax until the point of recovery of all contributions. At the same time, the contributions are not deductible when made under U.S. law. Where, however, the U.S. citizen becomes resident in Canada upon retirement, he will be taxed on the entire amount of pension benefits, notwithstanding the earlier non-deductibility-per Stephen v. $M N R^{14}$ and Raven v. MNR. ${ }^{15}$

\section{REGISTERED RETIREMENT SAVINGS PLANS}

\section{General}

The purpose of Registered Retirement Savings Plans (RRSP) is to extend the right to deduct contributions to all taxpayers whether employees or self employed. As such, the RRSP provides a vehicle for investment and deferment to a broader spectrum of taxpayers than do conventional pension plans. A RRSP is not, in the strict sense, an employee plan. However, in closely held corporations, where the principal shareholders are also employees, there may be an option to either contribute to an employee's deferred income plan or pay a higher salary and allow the individual to invest in a RRSP.

In essence, there are three types of RRSP's offered by trust companies and others in the field:

(i) guaranteed plans with fixed rates of return usually involve in-

\footnotetext{
1326 Tax A.B.C. 33.

14 33 Tax A.B.C. 330 .

is (1968) Tax A.B.C. 1097.
} 
vestments in fixed income securities such as bonds and mortgages;

(ii) managed plans which depend upon the performance of the investment. In this class, one may choose between low risk income plans, e.g. bonds and preferred shares, or high risk plans which offer a potential for rapid growth, e.g. common stocks;

(iii) self administered plans are those where an arrangement is made with a trust company, whereby the taxpayer actually directs the investments to be made through the medium of a stockbroker. At the same time, a management fee is paid to the trust company in return for the accounting and custodial services rendered by the latter.

\section{Registration}

In order that contributions to an RRSP "be" deductible from income for tax purposes, the plan must be accepted for registration by the MNR. The conditions for acceptance of registration are detailed in $s .146(2)$ and (3) and Information Circular No. 72-22. In general, the MNR will not accept plans that provide for payments of benefits before maturity, other than a refund of premiums. Further, the RRSP must provide for benefits to be paid after maturity by way of an annuity for life. The annuity may or may not have a guaranteed term, and where there is a guaranteed term it cannot exceed 15 years. Finally, the maturity date cannot be later than the day before the taxpayer's 71st birthday, and the annuity cannot be capable of commutation, surrender or assignment.

\section{Investments}

As with pension plans, RRSP's are subject to severe penalties in respect of non-qualifying investments. Part XI of the Act imposes a special tax at the rate of $1 \%$ per month on the lesser of the cost of "foreign property" acquired subsequent to June 18,1971 and the cost of "foreign property" in excess of $10 \%$ of all property-8.206(1), the tax being payable within 90 days from the end of each year-8.207(1).

With the exception of this special tax, the income of the RRSP is allowed to accumulate in the fund free of tax liability, with the benefits being taxable in the hands of the recipient upon distribution of the funds-s.146(8) and s.56(1)(h). However, an important exception to this rule is where amounts received are transferred to another statutory plan during the same taxation year, or within 60 days thereafter no tax liability is imposed on the taxpayer. Such rollovers do not affect the annual contribution limits.

\section{Deductibility}

RRSP's are governed by the provisions of s.146 of the I.T.A. The key to deductibility is that there must be a payment to purchase a pure annuity without any life insurance factor and without the benefit of the contract being available as collateral, without being assignable or being anticipated before maturity. The maximum annual deduction is the lesser of $20 \%$ of earned income or $\$ 4,000$, where the taxpayer does not belong to an employee's registered pension plan-s.146(5)(b). Where, however, the employee does belong to an employee's registered pension plan, he can only claim the amount remaining after deducting his allowable contributions to the employee's pension plan from the lesser of $20 \%$ of earned income or $\$ 2,500$. It should be noted, however, that even if 
the employee's pension plan is noncontributory, the taxpayer is still limited to $\$ 2,500-8.146(5)(\mathrm{a})$. The rationale behind this provision is that the employer may deduct up to $\$ 2,500$, thereby making the total deduction $\$ 5,000$ for the year.

Given the above provisions pertaining to the deductibility of contributions, the impact of potential tax deferment and thus tax saving is shown in Table $C$ below. These figures are based on the premise that the plan member is not also a member of a registered pension plan. It assumes that the taxpayer is a married man with two children under the age of 16 . The actual taxes will vary slightly from province to province.

TABLE C

\begin{tabular}{|c|c|c|c|c|c|}
\hline $\begin{array}{l}\text { Annual } \\
\text { Earned } \\
\text { Income }\end{array}$ & $\begin{array}{l}\text { Maximum } \\
\text { Deductible } \\
\text { Contribution }\end{array}$ & $\begin{array}{l}\text { Normal } \\
\text { Income } \\
\text { Tax }\end{array}$ & $\begin{array}{l}\text { Tax } \\
\text { With } \\
\text { RRSP }\end{array}$ & $\begin{array}{c}\text { Tax } \\
\text { Savings }\end{array}$ & $\begin{array}{c}\% 0 \text { of } \\
\text { Contribution }\end{array}$ \\
\hline $\begin{array}{r}\$ 5,000 \\
7,500 \\
10,000 \\
12,500 \\
15,000 \\
17,500 \\
20,000 \\
25,000 \\
35,000 \\
50,000\end{array}$ & $\begin{array}{r}\$ 1000 \\
1500 \\
2000 \\
2500 \\
3000 \\
3500 \\
4000 \\
4000 \\
4000 \\
4000\end{array}$ & $\begin{array}{r}\mathbf{2 9 6} \\
\mathbf{9 4 2} \\
1672 \\
2470 \\
3363 \\
4374 \\
5508 \\
7792 \\
12,742 \\
20,759\end{array}$ & $\begin{array}{r}\$ \quad 64 \\
540 \\
1088 \\
1672 \\
2307 \\
2994 \\
3768 \\
5965 \\
10,706 \\
18,514\end{array}$ & $\begin{array}{r}\$ 232 \\
402 \\
584 \\
798 \\
1056 \\
1380 \\
1740 \\
1827 \\
2036 \\
2245\end{array}$ & $\begin{array}{l}23 \% \\
27 \% \\
29 \% \\
32 \% \\
35 \% \\
39 \% \\
44 \% \\
46 \% \\
51 \% \\
56 \%\end{array}$ \\
\hline
\end{tabular}

\section{Tax and Investment Implications}

The principal effect of an RRSP is to provide an "interest free loan" from the taxing authorities. The taxpayer, by putting money into such a plan and deducting the contribution from his current income, permits his fund to increase by the amount of dollars that would otherwise have been paid as income tax. This "increased amount of dollars" may then be utilized by earning income which is free of tax, thereby providing an interest free loan. The impact of this interest free loan may be seen by considering two taxpayers $A$ and $B$, both 35 years of age, currently earning $\$ 19,000$ and desirous of retiring at age 65. (A marginal rate of $50 \%$ is assumed). If $A$ saves $\$ 1,000$ per year without the assistance of an RRSP, he will have $\$ 500$ to invest after tax, which at $6 \%$ will accumulate to $\$ 24,500$ in 30 years. For that principal sum he can purchase a life annuity of approximately $\$ 200$ per month. If B uses a RRSP, he may invest the entire $\$ 1,000$ which at the same rate of interest will accumulate to $\$ 83,801$ in the same time span. He may then purchase a life annuity of $\$ 700$ per month from his principal sum.

To this juncture it has been implicitly assumed that the taxpayer's marginal rate of tax will be lower upon retirement than during his peak earning years. This assumption, it is submitted, is reasonable in the light of known economic and statistical data. However, if one examines the alternative premise on the basis of conservatism, and assumes that the marginal rate of tax does not drop, the taxpayer is still found to emerge in a favourable light if only due to the time value of money. This hypothesis received the support of the former Finance Minister, Mr. Benson, who stated in reference to the White Paper of the Carter Royal Commission Report:

The royal commission showed that, under approved (registered) plans, it is possible at interest rates of 7 percent with only 20 years of saving, to get a 50 percent greater 
after-tax retirement income than by saving and investing outside such plans. With 40 years of saving, say from age 25 to 65 , it is possible to double the after-tax retirement income.

Table D compares the net annual after-tax retirement income for 15 years to be derived from retirement savings. It is based on the following assumptions:

(i) the before tax income available for saving each year is $\$ 1,000$;

(ii) the before tax investment income yields, of $5 \%$ and $7 \%$ a year for non-registered savings are assumed to be interest. If the income was generated from dividends, more favourable results would accrue due to the dividend tax credit;

(iii) marginal rates both before and after retirement are assumed to remain constant;

(iv) the retirement income is payable over 15 years in equal monthly installments and the taxpayer has other retirement income sufficient to make the above mentioned marginal rates applicable.

An analysis of the above figures indicates the substantial advantage which accrues from registration of a retirement savings plan.

$T A B L E D$

Net Annual After-Tax Retirement Income for Fifteen Years to be Derived from Retirements Savings

\begin{tabular}{|c|c|c|c|c|}
\hline \multirow{3}{*}{$\begin{array}{l}\text { Marginal Tax } \\
\text { Rate Before } \\
\text { and After } \\
\text { Retirement }\end{array}$} & \multicolumn{4}{|c|}{$\begin{array}{l}\text { Annual After-Tax Retirement Income for Each } \$ 1,000 \\
\text { of Annual Before-Tax Income }\end{array}$} \\
\hline & \multicolumn{2}{|c|}{$\begin{array}{l}\text { From } 20 \text { Years of Saving } \\
\text { with Investment Yield of: }\end{array}$} & \multicolumn{2}{|c|}{$\begin{array}{l}\text { From } 40 \text { Years of Saving } \\
\text { with Investment Yield of }\end{array}$} \\
\hline & $5 \%$ & $7 \%$ & $5 \%$ & $7 \%$ \\
\hline $30 \% \mathrm{NR}^{*}$ & $\$ 1,720$ & $\$ 2,190$ & $\$ 5,140$ & $\$ 7,905$ \\
\hline $\mathrm{R}^{* *}$ & 2,230 & 3,150 & 8,145 & 15,345 \\
\hline $40 \% \mathrm{NR}$ & 1,350 & 1,565 & 3,790 & 5,135 \\
\hline & 1,910 & 2,700 & 6,985 & 13,150 \\
\hline $50 \% \mathrm{NR}$ & 1,030 & 1,230 & 2,720 & 3,670 \\
\hline $\mathbf{R}$ & 1,595 & 2,250 & 5,820 & 10,960 \\
\hline
\end{tabular}

*NR: Non-registered savings plan: the annual contribution is not deductible because the plan is not registered and therefore the amount saved would be the balance after the applicable tax liability had been paid.

**R: Registered plan: the annual contribution is deductible for tax purposes so the full amount of income available is paid into the retirement income plan. The investment income is exempt from tax when earned. Benefits are taxable when received.

A further advantage of a RRSP is the use of the funds in estate planning. Under normal circumstances, the marginal rate of tax of a husband is greater than that of his wife. Hence, the husband obtains the benefit of deducting his contributions at his high marginal rate of tax; upon his death, his widow need only pay the tax on the income at her rate of tax. If, as is usual, her rate is lower than her husband's an added benefit has been derived.

Since the taxpayer will pay tax on his proceeds from the RRSP, any financing charges on borrowed funds may be considered as an expense properly deductible in computing current income. The Department takes the view that interest expense is an expense of earning income from property and may be deducted. Table $\mathrm{E}$ shows the tax and investment consequences for a taxpayer who borrows $\$ 2,000$ per year for 20 years at a cost of $7 \%$ interest and invests the proceeds at $6 \%$ compounded. A marginal tax rate of $50 \%$ is assumed. 
TABLE E

Funds Borrowed Each Year

Total Funds Borrowed over 20 years

Interest charges at $3 \frac{1}{2} 2 \%$ per annum (marginal rate of tax $=50 \%$ )

$\$ 2000$ 40,000

Total Debt

Funds Invested Each Year:

From Borrowed Money

From tax saving on $\$ 4000$

annual contribution

Total Funds Invested Each Year

Invested at $6 \%$ per annum for 20 years
18,000

58,000

2000

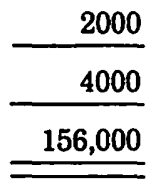

The above table shows that the taxpayer will be entitled to proceeds of $\$ 156,000$ in 20 years. This principal is sufficient to purchase an annuity of $\$ 1,300$ per month for life, thereby providing an annual income of $\$ 15,600$. If the taxpayer has a retirement marginal rate of $40 \%$ he will receive net after tax proceeds of $\$ 9,360$ per year. He can afford to pay off the debt in 7 years and then proceed to live on his annuity for his remaining days. From a practical point of view, the taxpayer may have some difficulty in obtaining such credit terms as outlined in the above example. However, the illustration does highlight the convenience of deducting interest charges for contributions to RRSP's.

It is well at this point to consider a major disadvantage of RRSP's, in that the taxpayer will be taxed on any and all capital gains as if they were normal fully taxable income. Thus, a RRSP has the effect of converting capital gains into income, a distinct disadvantage in the light of the different effective rates of tax applicable. Table $F$ considers the position of two taxpayers, one with and the other without a RRSP. Assuming the availability of $\$ 1,000$ for investment purposes per year and a rate of return of $8 \%$ compounded over 10 years, the table shows that taxpayer $B$ (without RRSP) may be better off if the following additional assumptions apply:

(i) A deregisters his plan while still making a taxable income of \$5,000 . B also has $\$ 5,000$ taxable income in year 10 .

(ii) A does not reinvest his proceeds in a new RRSP.

(iii) B's portfolio increases solely by capital gains. i.e. $\$ 3,544$ is capital gain of which $\$ 1,772$ is taxable.

\section{TABLE F}

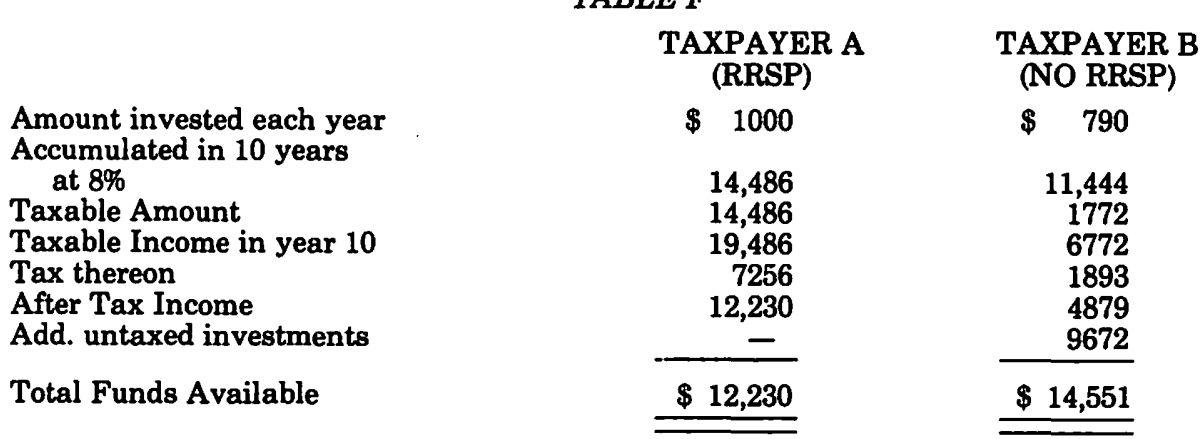


Thus, taxpayer $B$ is better off by $\$ 2,329$ at the end of 10 years. To prevent such a result taxpayer $A$ could have adopted several alternative courses of action. Thus he could have contributed to more than one plan and deregistered in another year. Again, he could have purchased an income averaging annuity and further deferred tax. Finally, it is unlikely that taxpayer $B$ would accumulate his entire fund in the form of capital gains.

Before leaving this section, it is submitted that the policy implications of 8.146 of the I.T.A. are worthy of note. The concept of the RRSP offers greater scope for individual initiative. From a macroeconomic point of view, such plans may serve to dampen the clamour for greater old age assistance. In addition, liquidity in the Canadian capital markets will be enhanced since RRSP's must be $90 \%$ invested in Canadian situations. Finally, it may be suggested from the point of view of fiscal policy, that such plans act as built-in stabilizers to the extent that they would tend to be deregistered during times of financial hardship, unemployment and economic recession.

\section{DEFERRED PROFIT SHARING PLANS}

\section{General}

A Deferred Profit Sharing Plan (DPSP) is defined in s.147(1)(b) as an arrangement under which an employer makes payments to a trustee for the benefit of employees of amounts which are computed by reference to his profits from his business. It is still another vehicle to provide retirement benefits at some time in the future, together with tax sheltered growth of contributions made in relation to profits. As with RPP's and RRSP's previously discussed in this paper, the DPSP must be accepted by the MNR, before contributions are eligible for deduction. For this purpose, application should be made in the manner prescribed by Regulation 1501. Further, s.147(2) outlines the statutory requirements which must be fulfilled before the MNR will accept a profit sharing plan as a DPSP.

The nature of a DPSP was considered by the Supreme Court of Canada in $M N R$ v. Lade. ${ }^{16}$ In that case, the taxpayer was an employee of Richfield Oil Corporation and participated in the company's stock purchase plan. The participants agreed to make monthly contributions to the trustee and the corporation agreed to add further amounts equal to $50 \%$ of the employee's contributions. The corporation also agreed to make additional annual contributions under the plan if its profits exceeded $11 \%$ of its invested capital. The issue to be determined by the Supreme Court of Canada was whether or not the company's contributions were computed by reference to its profits from its business. The Court held that the plan was not a DPSP. Cartwright J., delivering the unanimous opinion of the Court: ${ }^{17}$

In my opinion, an arrangement under which the amount of payments made by an employer is fixed by the amount contributed by his employees, regardless of whether he does or does not make a profit, is not brought within the definition ... merely because the employer agrees to make an additional payment in those years, if any, in which his profits exceed a certain ratio.

As a consequence of this decision, the Department now requires that certain minimum contributions be set forth in any plan if it is to qualify for

16 [1965] C.T.C. 525.

17 Id. at 529. 
registration; therefore, the employer must make a minimum contribution for each member of the plan.

In contrast to RPP's and RRSP's which may be employee triggered, the DPSP is an employer triggered plan. Of particular interest is the provision of $s .147(2)(i)$, which stipulates that all amounts allocated or reallocated by the trustee must vest irrevocably in the beneficiary within five years after the end of the year, unless the beneficiary has in the meantime ceased to be an employee. Further, in order that contributions be deductible there must be an employer-employee relationship. As a consequence, a sole proprietor or a partner will not qualify as a member of a DPSP even though he may set up a DPSP for his own employees.

In addition to the statutory requirements of the I.T.A., the Minister has certain implied powers pursuant to s.147(1)(a). Pursuant to these implied powers, the Department has laid down the following additional departmental rules:

(i) For non-public corporate employers, at least one of the trustees should be independent of the operations of the company and should not be a shareholder.

(ii) The plan should define normal retirement age.

(iii) The plan should provide for vesting of all allocations at retirement on account of age or disability even though five years have not passed since the allocation was made.

(iv) Divesting because of dismissal for cause should not be permitted.

(v) The trustees should have sufficient authority as to ensure the implementation of the plan and the payment of benefits to beneficiaries.

(vi) The plan should specifically prohibit the payment of any amount to an employee or other beneficiary by way of loan.

(vii) The plan must not include any provision for divesting a beneficiary because of union membership nor may it interfere with the subsequent vesting of allocations in years prior to such union membership.

Over and above all the various specific statutory and Departmental provisions, it is imperative that the DPSP be a "legitimate" plan and not a mere sham. The impact of $8.245(1)$ is as rigorous in this area as it is in the other areas of the I.T.A. An illustration of this rigour may be seen in Hamilton Motor Products Ltd. v. MNR, ${ }^{18}$ where the taxpayer applied for and obtained approval for a DPSP shortly before selling his business. Under the terms of the DPSP, the employer paid $\$ 103,500$ which was allocated to employees, with a limit of $\$ 1,500$ per employee. However, when the regular employees were discharged, they received only $\$ 19,000$, with the remainder being reallocated to the principal shareholder and his brother. Despite prior approval, the Minister disallowed the $\$ 103,500$ deduction. The Exchequer Court upheld the MNR's contention, Gibson J., observing that the plan was ". . . beyond any doubt ... . a transaction or operation that was designed to artificially reduce the income ...".

\section{Qualified Investments}

DPSP's are restricted in the type of investments which they may

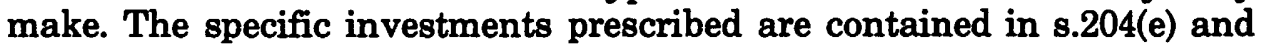


in several regulations, most notably No. 1502. In general, these investments include:

(i) Deposit accounts with Canadian banks, trust companies and credit unions.

(ii) Bonds, notes and debentures issued by federal and provincial governments or guaranteed by them.

(iii) Bonds, notes and debentures of a corporation whose shares are listed on a prescribed stock exchange in Canada. (Note, however, that s.147(2)(c) provides that no trust funds may be invested in notes, bonds, debentures or similar obligations of the employer, a corporation with whom the employer does not deal at arm's length or in the shares of a corporation whose value consists of at least $50 \%$ in such obligations of the employer).

(iv) Shares listed on a prescribed stock exchange in Canada.

(v) Guaranteed investment certificates issued by a Canadian trust company.

(vi) Certain investment contracts approved by the Governor-inCouncil.

(vii) Other investments prescribed by regulation including certain mutual funds, certain trust company pooled funds, annuity policies, etc.

(viii) Certain other investments, provided they comply with special rules, including equity shares of a corporation listed on a prescribed stock exchange outside Canada. Reinvestment in the shares of the employer's corporation is not expressly prohibited, but if the employer is a private company the shares must meet the requirements of ss.204(1)(e)(vi) and 257(2)(3). Such shares are rare. Note that shares subject to a buy-sell agreement will not qualify if the agreement limits their transferability.

(ix) Certain life insurance policies (covered by special rules in s8.198(6) and (7)).

While in the past DPSP's had very wide powers to invest funds and did quite often reinvest funds back into the employer corporation, s.204(1)(e)(vi) now restricts the type of equity shares available for investment. To qualify as an investment, the equity shares must not have any restriction on their transferability, and in each of the four taxation years out of the immediately prior five consecutive have paid a dividend on each share of the class of not less than $4 \%$ and have earned not less than $4 \%$ per share. This definition of equity shares permits two categories; one to receive special $\mathrm{s.83}$ dividends and the other normal taxable dividends.

The importance of investments being of the qualified category cannot be overstated. Under s.198(1) a penalty tax of $100 \%$ is imposed on investments that do not qualify as well as on property of a trust used as security for a loan. While the tax is refundable, the amount of the refund is the lesser of the penalty tax paid or the amount received on the disposition of the unqualified investment, thereby creating situations where only a partial refund will be obtained. In addition, a non-refundable tax of $1 \%$ per month may be levied under s.206(1) on all foreign assets exceeding $10 \%$ of the total cost of all property by the DPSP trust. There is also the possibility of a $1 \%$ per month tax under s.207.1(2). 


\section{Tax and Investment Implications}

Where a DPSP has been accepted by the Department, the employer may deduct contributions to the plan in accordance with s.147(8). The maximum amount deductible by the employer is the lesser of:

(i) $\$ 2,500$, or

(ii) $20 \%$ of salary; (not "earned income").

Where, however, the employer also contributes to a registered pension plan in respect of the employee, the maximum deductible amount under both plans, may not exceed $\$ 2,500$. Hence, where an employee earns $\$ 20,000$ per year and the employer contributes $8 \%$ to a RPP, i.e. $\$ 1,600$, the employer's deduction for his contribution to the DPSP would be $\$ 900$, being the lesser of $\$ 2,500-\$ 1,600$ or $20 \% \times \$ 20,000=\$ 4,000$.

An important advantage of a DPSP, from the employee's point of view, is that he retains the option to contribute up to $\$ 4,000$ to an RRSP. Although employee contributions to a DPSP are not deductible from income, the employer's contribution does not restrict the employee from obtaining a total tax shelter of $\$ 6,500$; i.e. $\$ 2,500$ to DPSP by employer and $\$ 4,000$ to RRSP by employee. This $\$ 6,500$ tax shelter compares with $\$ 5$,000 if the employer contributed to a RPP. At the same time, the employer is not prejudiced in any way, in that his contribution remains at $\$ 2,500$ whether to a RPP or to a DPSP.

The full impact of the tax savings involved may be observed from the following figures. Assuming a marginal tax rate of $40 \%$ and investment of proceeds at $7 \%$ compounded, Table $G$ outlines the costs and savings involved.

$\begin{array}{lccc} & \text { TABLE G } & & \\ \text { Fund Value } & 10 \text { Years } & 15 \text { Years } & 20 \text { Years } \\ \text { Contributions } & \$ 32,717 & \$ 59,313 & \$ 95,276 \\ \text { Tax Savings } & 25,000 & 37,500 & 50,000 \\ \text { Net Contribution } & 10,000 & 15,000 & 20,000 \\ & 15,000 & 22,500 & 30,000\end{array}$

In contrast, if the $\$ 2500$ was invested in Canada Savings Bonds at an annual rate of $7 \%$ compounded, the following principal sum would be available in 10 years.

TABLE $H$

Original Earnings

$\$ 2500$

$40 \%$

Net Proceeds available for investment after tax

Total Proceeds in 10 years after tax on interest

There would appear to be a further distinct advantage available to a DPSP that is not available to a RPP. As observed earlier, "Top Hat" pension plans are no longer available and such plans cannot be structured for the primary benefit of significant shareholders. In contrast, it would appear possible to put a DPSP into operation for the benefit of a controlling shareholder who is also an employee. Since the DPSP is by definition not a pension plan, but rather a plan related to the profits of an enterprise, it would logically be available to those employees who are essential to the profitability of a corporation. In the case of most closely 
held corporations, such an individual is usually, though not necessarily, the majority shareholder.

\section{Taxability of Benefits}

The income of the DPSP, itself, is exempt from taxation during the tenure of the trust and, as such, funds may accumulate on a tax free basis. Rather, when payments are made to the beneficiary, such benefits become taxable under s.147(10). At that time several options, discussed later, are available to the taxpayer with a view of deferring or reducing the tax burden. Where, however, an employee or former employee dies, withdraws or retires from employment, and

(i) the beneficiary is a resident of Canada,

(ii) a single payment is made by the trust,

(iii) the single payment includes property other than money, and

(iv) the beneficiary makes the prescribed election, in prescribed manner and form,

then, any accrued capital gains of the DPSP after 1971, to the extent that they do not exceed the fair market value (FMV) of the property at the time of distribution, will not be included in income. Thus, where a beneficiary receives a single payment of shares having a cost of $\$ 25,000$ and a FMV of $\$ 40,000$ and the property represents his share in the DPSP of allocated income and capital gains of $\$ 35,000$, as well as accrued but unrealized capital gains of $\$ 5,000$ at the time of distribution, then the $\$ 5,000$ will be excluded from the employee's income by $8.147(10)$ and only the $\$ 35,000$ will be subject to tax.

In conclusion, a DPSP may be said to offer a strong mix of guarantees, equity based and insurance protection, which insurance protection guarantees a larger payout on death, even where such death occurs in the early years of participation. Further, tax free transfers may be made to alleviate the burden of immediate taxation. At the same time, the freedom from fund management and valuation problems will prove attractive to many executives concerned with compensation policies.

\section{LOANS}

The cost of borrowing money by an employee to enjoy a standard of living is a very real cost. Most people, including executives, are required at one time or another to borrow funds in order to finance their major purchases. In the usual situation, the cost of borrowed funds may run from $12-16 \%$, which in turn requires an employee executive to earn pretax income of $24-32 \%$, if the marginal rate of tax is $50 \%$, in order to repay the interest on any such loan. Hence, an employee requiring $\$ 1000$ to pay interest in any given year must earn $\$ 2000$ incremental pre-tax income in order to finance his loan. At some point in time, the pressure for additional remuneration will make itself felt on the employer through employee demands.

When, and if, such pressure is exerted the corporate employer may consider as one alternative, providing the employee with an interest free loan. Under this alternative, the employee escapes taxation on any imputed benefit derived from an interest free (or low interest) loan and his demands for higher pre-tax income are abated, at least to some extent. In our illustration above, the employer could loan the employee $\$ 10,000$ at zero per cent interest to assist in financing a home purchase. At a market interest rate of $10 \%$, the employee derives a benefit of $\$ 1000$ im- 
puted interest without the ravages of taxation. In effect, the employee receives the equivalent of a $\$ 2000$ benefit if he had been paid by salary (assuming a $50 \%$ marginal rate).

In this context, although s.6(1)(a) stipulates that there shall be included in the income of a taxpayer as income from an office or employment "... the value of board, lodging and other benefits of any kind whatsoever... received or enjoyed by him in the year in respect of, in the course of, or by virtue of an office or employment...," this provision does not appear to catch interest free loans. In No. 359 v. $M N R,{ }^{19}$ the appellant taxpayer had borrowed $\$ 97,000$ from the company of which he was a shareholder and officer. No interest was paid on the loan. The MNR included in the taxpayer's income imputed interest at the rate of $4 \%$ and relied on the equivalents of $s .6(1)(a)$ and s.15(1)(c) of the former Act. The appeal was allowed by the Tax Appeal Board. In giving judgment, W. S. Fisher, Q.C. observed:20

\begin{abstract}
Apart from specific legislation in a taxing statute, I know of no law which imposes an obligation upon a lender to demand the payment of interest in connection with a loan granted by the lender to a borrower, and if the lender does not require the payment of interest, the borrower is under no obligation to pay interest.
\end{abstract}

Further, the Board observed that the issue as to whether the lending company was using its funds judiciously was totally irrelevant.

Again, in Wale v. $M N R,{ }^{21}$ the appellant taxpayer had borrowed $\$ 15$,000 from a corporation of which he was a shareholder. No interest had been charged and this time the MNR sought to impute a taxable benefit at a rate of $6 \%$ interest. Once again, the Board held that a lender was not obliged to charge any interest and the appeal was allowed. A similar issue was presented to the Exchequer Court in $M N R$ v. Pillsbury Holdings Limited, ${ }^{22}$ where an interest bearing demand loan was made, and the interest was waived before the due date. The Court held that there is no requirement on the part of the employer to charge interest on a loan, nor is there any obligation on an employee to pay or have imputed to him any interest income or benefit. It is submitted, however, that had the employer waived the interest after the due date in the Pillsbury case, there may well have been an imputed taxable benefit.

It is axiomatic that where such interest free funds are provided, the lending employer is deprived of the benefit of the loaned funds and cannot deduct as an expense the imputed interest charge. However, the employer corporation is not necessarily out of pocket any more than it would have been if it had increased the direct remuneration of the employee in the form of salary. In order to put the employee in the same position, it would, in our illustration, have had to pay $\$ 2000$ incremental salary at a net-after tax cost of $\$ 1000$. By lending the employee $\$ 10,000$ and assuming an imputed rate of return of $20 \%$, the employer is out $\$ 2000$ before tax and $\$ 1000$ after tax. Meanwhile, the employee has obtained a definite tax advantage, not to mention the increased loyalty and commitment to his employer.

Where the officer or employee is also a shareholder, the tax planner

\footnotetext{
${ }^{19} 56$ D.T.C. 475.

20 Id. at 477.

25 (1964) 36 Tax A.B.C. 255.

22 [1964] C.T.C. 294.
} 
should be cognizant of the provisions of $8.15(2)$, which is designed to prevent the withdrawal of funds from a corporation in the guise of a loan. Section 15(2) provides that where a corporation has in a taxation year made a loan to a shareholder, the amount of the loan is to be included in the income of the shareholder, unless certain exceptions specified in s.15(2)(a) are complied with. (Unlike s.8(2) of the former Act, the amount is not treated as a dividend, and hence is not eligible for a dividend tax credit).

In this context, the source of the corporation's funding is immaterial. Thus, the corporation may make the loan out of undistributed income on hand or may put itself into a deficit position. If the loan is not exempted by the specific exemptions listed, the loan is included in the shareholder's income for the year. For the purpose of this computation the words "taxation year" are interpreted as the taxation year of the shareholder and not that of the corporation. In the usual case this will

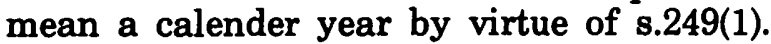

It is important to distinguish between a loan to a shareholder and a return of capital. While the former is taxable under s.15(2), the latter is not. In Tremblay v. MNR, ${ }^{23}$ the two appellants organized a company in 1956. Within a year, the appellants decided to go into business on their own and proceeded to take "advances" from the company on the assumption that what they drew from it would be offset by the amount of capital distributed on winding up. The MNR taxed the $\$ 23,500$ received as a loan, but was over-ruled by the Tax Appeal Board, which held that the "advances" were not loans because the appellants never undertook to repay them.

While it may appear attractive at first blush to circumvent the provisions of s.15(2) by making the loan to the shareholder's wife, rather than to the shareholder directly, this avenue of escape is effectively blocked by $s .56(2)$, which invokes the principle of "constructive receipt". Thus, where property is transferred with the concurrence of a taxpayer to some other person for the benefit of the taxpayer, or as a benefit that the taxpayer desired to have conferred on the other person for the benefit of the taxpayer, or as a benefit that the taxpayer desired to have conferred on the other person, the amount shall be included in computing the taxpayer's income.

An illustration of the above cited provision may be seen in Reiniger v. $M N R .^{24}$ There the company, of which the appellant was the principal shareholder, advanced as loans to the appellant and his wife, who held one share, amounts of $\$ 6156$ and $\$ 4351$ respectively. The wife's loan was held to be taxable in the hands of the appellant shareholder under s.56(2). It is interesting to note that, in this particular case, the Board was assisted in its decision that the loan was a benefit because of the absence of any stipulated interest rate. The Board observed: ${ }^{25}$

It seems to me more than doubtful that any bank, or other financial institution, would have lent money to the appellant's wife on such easy terms-or even at all, for that matter-and that, accordingly, what she derived from the company's action was a benefit within the meaning of $8.16(1)$ [8.56(2)].

Surely, this is inconsistent with the view, earlier expressed, that a company may use its funds as judiciously or injudiciously as it desires. The

\footnotetext{
23 (1963) 31 Tax A.B.C. 69.

24 (1968) 20 Tax A.B.C. 242.

25 Id. at 246.
} 
decision could equally well have been founded on the simple premise contained in s.56(2) that an indirect payment had been made with the concurrence of the appellant, and hence he was in constructive receipt of the funds.

Having noted those situations where loans to shareholders do not operate to the advantage of the shareholder, one may examine those situations where such loans may be made without adverse tax consequences. Section 15(2)(a) s.s. (i)-(iv) outline the conditions where such loans may be made to shareholders, provided that bona fide arrangements are made for repayment of the loan in a reasonable time. An executive shareholder may beneficially use these exceptions to obtain a loan to finance the purchase of a home, shares of the corporation or an automobile.

To exempt the loan under s.s. (ii), the shareholder must also be an officer/employee. The phrase "dwelling house" is interpreted broadly enough to include a summer cottage. Again, while the shareholder will usually be expected to occupy the dwelling acquired under s.s. (ii), he may justifiably be prevented from doing so for some legitimate reason, without the danger of losing his exemption. Hence, in Morin v. MNR, ${ }^{26}$ the shareholder obtained a loan of $\$ 15,000$ to purchase a house in another city, where he proposed to transfer. Later, the transfer was aborted and he unsuccessfully put up his newly acquired house for sale. He then rented the house without losing the benefit of the s.s. (ii) exemption. Whether or not the shareholder can acquire a loan and then immediately sell the home for some other reason not equally as legitimate as the above, and still retain a tax free loan is a moot question.

Once the door is opened and a loan is made to the shareholder under s.15(2)(a), in order to avoid inclusion in income, bona fide arrangements must be made for repayment of the loan within a reasonable time. What is bona fide and reasonable must of necessity be questions of fact. Presumably, a loan to acquire a house may be repaid over 20 to 25 years, as this would be a reasonable time in the context of a conventional home mortgage. When one considers the current rate of mortgage charges at $10-12 \%$, a substantial loan over a 25 -year period provides the shareholder with a significant alternative compensation scheme, in contrast to conventional cash remuneration. As indicated earlier, a taxpayer in the $50 \%$ bracket would have to earn an incremental $20-24 \%$ pre-tax income to finance the transaction under discussion.

Should the shareholder fail to qualify under one of the s.15(2)(a) exceptions, he may still receive indirect compensation through the judicious use of $s .15(2)(b)$. While this paragraph is not nearly as lucrative an avenue for enhanced compensation, it does offer possibilities, especially where the amounts involved are substantial. Section 15(2)(b) requires that a loan received by a shareholder must be included in his income, unless the loan was repaid within one year from the end of the taxation year of the corporation in which it was made. Given this provision, a shareholder may obtain a loan of $\$ 200,000$ from his company which has a January 1 , year end. The shareholder borrows the money on January 2,1973 , and the loan is thus not due back until January 1,1975 by s.15(2)(b). In 1975 , the $\$ 200,000$ is deemed to be income for that year. However, the shareholder may still pay back the 
loan by December 31, 1975, and obtain a full deduction under s.20(1)(j).

In this manner, the shareholder has effectively had a loan of $\$ 200,000$ for a period of three years without any interest charge. At current market rates of interest of $12 \%$, he has derived an equivalent of $\$ 81,000$ pre-tax income, if he invested the proceeds at the going market rate. While this scheme is not nearly as advantageous when the receipt is in the form of income, it has distinct possibilities when the receipt is in the form of capital gains, due to the effective lower tax rate on such gains.

As observed earlier, the scheme for repayment must be bona fide. In Cadrin v. $M N R{ }^{27}$ the appellant shareholder had obtained several loans from his company. The loan balance rose from $\$ 50,155$ in 1961 to $\$ 86,328$ in 1962 , then to $\$ 206,700$ in 1963 and finally to $\$ 244,180$ by the end of 1964. The taxpayer had made a series of repayments over the years, and there was considerable activity in the account. He contended that the payments should be applied on a first-in, first-out basis, so as to ensure repayment within the one year rule. The contention failed and the repayments were held to be part of a series of loans and repayments.

Again, in Johnston v. $M N R^{28}$ the appellant, deceased, had received loans from a company of which he was the principal shareholder. In purported repayment of a loan of $\$ 12,000$, the appellant had executed a mortgage, of that amount, on his residence, in favour of the company. The appellant contended that the mortgage constituted payment and was not given to the company merely as security for repayment of the loan, but rather as a reduction of $\$ 12,000$ of indebtedness. The Tax Appeal Board accepted the intention of repayment, but nevertheless, held the appellant taxable. The Board noted: 29 " ... while I am prepared to assume that the deceased did intend the mortgage to operate as payment ... the statute requires repayment in money or money's worth, but where repayment is being made in money's worth, the burden is on the taxpayer to prove the sufficiency in all respects of such repayment ...". As the case stands, it is uncertain whether the Board did not consider a mortgage as money's worth, or whether the evidence as to its worth was insufficient.

A more exotic device of repayment may be seen in Turner v. MNR.30 In that case, the appellant shareholder attempted to repay advances of $\$ 21,458$ by transferring ownership of a private aircraft to the company controlled by him. In purported compliance with this transfer, an entry was made on the company's books of account. However, the registration remained in the appellant's name. The appeal was dismissed and the taxpayer had to include the amount in income. The Board felt that "... the appellant was using his company as his personal tool. He was drawing money that he never reimbursed to comply with the provisions of the Act...".

The above discussion indicates the immense value of $\mathrm{s.15}(2)$ in providing an executive shareholder with indirect and non-taxble compensation. While s.15(2)(a) is certainly a more beneficial device, s.15(2)(b) may prove to be quite effective in the short run, provided there is strict compliance with the Act, as indicated by the cases cited. In all of these situations described, the employer corporation loses funds to the extent

\footnotetext{
27 (1969) Tax A.B.C. 824.

28 (1964) 35 Tax A.B.C. 18.

29 Id. at 29.

${ }^{30}$ (1969) Tax A.B.C. 180.
} 
that it has funds locked into these schemes. However, two arguments may be made to counter this disadvantage to the employer. First, in the absence of such indirect compensation, the employer would face alternate pressure for increased direct compensation. Second, where an executive is in the higher tax brackets with marginal rates of $65 \%$, the saving to him is greater than the loss to a corporation paying $46 \%$ or less corporate tax. This argument assumes greater credibility where the corporation is controlled by one principal shareholder and his family.

\section{General}

\section{STOCK OPTIONS}

The purpose of this section is to examine the nature and value of stock options as part of a scheme of compensation for executives. That this alternative form of compensation has advantages peculiar to certain situations and associated disadvantages will become evident in the following discussion. A stock option is a contract right where by an employee may acquire shares of the employing company or an affiliated company at a predetermined price. Since the right is contractual in nature, the period of time in which the shares may be acquired, the price of the option etc. will vary according to the agreement. In the usual situation, the employee will exercise his option at a time when the price of the stock on the market is higher than the cost of the option.

The governing provisions of the Act in respect of stock options are contained in 8.7. At the outset, it may be observed that there is an advantage for a benefit being classified under s.7 rather than $8.6(1)(a)$, since the latter provides for immediate inclusion into income, whereas the former provides for a certain measure of tax deferment with its resultant advantage. By 8.7, the recipient employee is taxed on the basis of a benefit having been received from participation in the stock option plan by virtue of employment. The benefit is taxable as employment income and not as capital gains, with the employer receiving no corresponding deduction.

Section $7(1)(a)$ requires an agreement, and once it is established that the benefit was received by virtue of the agreement, the amount becomes taxable under the section. In practice, the agreement may be written or oral. In G. G. Smith v. $M N R^{31}$ a private company issued 1850 preference shares to its president in return for $\$ 200$. Since the preference shares had a par value of $\$ 10$, the president derived a benefit of $\$ 18,300$, which he declared in his tax return, but sought to pay tax in accordance with s.85(A)(2) of the old Act. The MNR refused on the ground that there was no "agreement" with the company. The Board allowed the taxpayer's appeal on the evidence of an oral agreement, observing:32

It should be borne in mind that from a business and personal point of view, a private company is more analogous to a partnership than to a public corporation ..... Accordingly, one does not look for the same strictness of formality in the recording of internal agreements.

Thus, the benefit to be taxed under 8.7 must be derived pursuant to an "agreement" $-8.7(1)(a)$, and by virtue of the employment-s.7(5). There is a considerable collection of jurisprudence as to who is an employee, ranging from the ancient English cases to the

31 (1969) Tax A.B.C. 217.

32 Id. at 220. 
pronouncements of the Supreme Court of Canada. In The City of St. John v. Donald, ${ }^{33}$ Anglin C.J.C., quoted with approval the test laid down in an earlier case, ${ }^{34}$ as follows:

The final test, if there be a final test, and certainly the test to be generally applied lies in the nature and degree of the detailed control over the person alleged to be the servant. This circumstance is, of course, only one of several, but it is usually of vital im. portance.

As suggested in DiFrancesco v. $M N R$, ${ }^{35}$ the word "servant" has become somewhat archaic and perhaps "employee" might well be substituted. The presence of an agreement is imperative to derive the benefits of forward averaging provisions applicable to 8.7 benefits. Hence, in Fowler v. $M N R{ }^{36}$ where a retiring employee received shares under a voluntary bonus plan from his employer, it was held not to be taxable under this section.

Further, the transfer must be from the company to the employee and not from another officer or shareholder, as seen in $M N R$ v. Tomkins. ${ }^{37}$ There, the appellant received his shares which, at the pertinent time, were held in escrow as parts of blocks of shares issued to the president. The taxpayer failed in his attempt to invoke the averaging provisions of the Act, it being held that the escrow shares made available to the taxpayer were the personal property of the president and there was no agreement whereby the companies had agreed to sell or issue shares to the taxpayer. Again, if the person receives the shares qua shareholder and not as an employee, he falls under the provisions of 8.15 and not under 8.7 , per the decision in No. 513 v. MNR. ${ }^{38}$

\section{Taxation of Benefits}

Section 7 deems the difference between the amount that the employee was required to pay for the stock and the market price of the stock on the day acquired as a taxable benefit. Hence, where a stock is trading at $\$ 50$ and the employee acquires it for $\$ 40$, a benefit of $\$ 10$ times the number of shares acquired made available by the option will be deemed to be the benefit. There are several advantages from the point of view of the employee:

(i) Such plans permit the employee to acquire an interest in the corporation and the employee is tied into the fortunes of the company. (At the same time, he is tied into the fortunes of the stock market in general.) Such schemes, by providing a vested interest in the company stimulate incentive and motivation to improve the operations of the employer, and link the employee's energies to the success of his employer.

(ii) At the same time, the employee is not required to commit any of his personal funds, other than that for the payment of taxes, nor does the employee suffer as greatly from any misfortune which may befall the company. He simply lets his option lapse rather than exercising it.

(iii) To a certain extent, stock options tout the rank of an executive in

\footnotetext{
33 [1926] S.C.R. 371

34 Performing Right Society v. Mitchell \& Booker (1974) 1 K.B. 762 at 767.

35 (1964) 34 Tax A.B.C. 380 at 384.

${ }^{36}$ (1963) 32 Tax A.B.C. 353.

${ }^{37}$ [1963] C.T.C. 258.

ss (1958) D.T.C. 301.
} 
the corporation and, where this is important to the individual, may act as a form of non-monetary reward.

Against these advantages, the employee may, despite his best efforts, and notwithstanding the success of the corporation, become subject to the vagaries of the stock market. He may become the victim of political and extraneous factors which may adversely affect the market in general, while having no direct relationship to his company. Again, such plans often embody restrictive clauses tying in the employee to his company and reducing his mobility in the employment market.

From the employing corporation's viewpoint, there is an advantage in that it is required to expend less in cash and provide more in benefits. To a young enterprise with cash flow problems, this may prove to be invaluable. Further, when the option is exercised, it provides an injection of equity capital and is the equivalent of an equity issue. At the same time, the vesting provisions of such plans are an inducement to retain executive talent.

The major disadvantage to the employer is that the company does not obtain any deduction for tax purposes and as such, there may be no real incentive to provide such plans other than by reducing real cash salaries. In the light of these considerations, it may prove advantageous for the company to provide a bonus to the employee equal to the difference between the FMV of shares and what would have been the option price. The company can then deduct the bonus as an expense and the employee is in the same cash position as before, except with one additional thorn in his side; the employee will no longer have the forward averaging provisions available to him and, therefore, no tax deferral mechanism.

An alternative approach, to circumventing the deductibility problem, might be for the employer corporation to buy shares of a related corporation on the open market, selling these to the employee as a s.7 option benefit and deducting any resulting capital loss against other capital gains. Section 54(c) of the Act defines "disposition" and specifically excludes ". . . any issue by a corporation of a share of its capital stock, or any transaction, but for this sub-paragraph, would be a disposition by a corporation of a share of its capital stock...". No mention is made of the shares of a related company. If one continues on to argue that s.7(3)(b) is a carryover of the old s.85A rules which did not contemplate capital losses, the argument may hold water.

\section{Valuation of Shares}

Where the securities in question are listed on a Stock Exchange, there is really no valuation problem in respect of stock options, the value simply being the fair market value of the stock. Where, however, the securities are unlisted or where there is no open market available, problems may arise. At that time, some formula which is acceptable to the DNR, must be devised. In computing the formula, the factors to consider would include whether the shares acquired constitute a controlling interest, whether the company's continued prosperity is dependent on one man or some trade or business consideration. In No. 179 v. $M N R{ }^{39}$ Mr. Fordham enumerated some of the factors which the court might con-

39 (1954) 11 Tax A.B.C. 76. 
sider in the absence of an open market for shares which did not transfer control. These included:

(i) book value as reflected in the company's accounts, or alternatively, adjusted book value;

(ii) past earnings with necessary adjustments from profit and loss accounts;

(iii) estimated maintainable profits considered with reference to past results;

(iv) earnings value and dividends value.

Further: 40 "The order in which these factors are considered is not of importance as, in the final analysis, the company's position must be viewed as a whole and in the light of all known facts and circumstances. Goodwill, business conditions and the company's methods of operation merit review. Furthermore,-and this is of marked importance-regard must be had to whether majority or minority shareholdings are involved, the former being given a higher value...".

\section{Capital Gains Treatment}

Since the advent of capital gains taxation which was introduced on January 1,1972 , the disposition of shares acquired under an employee stock option plan gives rise to several new considerations not found under the prior Act. Specifically, s.38 defines a taxable capital gain as onehalf of the capital gain arising on the disposition of any property. Again, s. 40 defines "gain" as the proceeds of the disposition less the aggregate of:

(i) the ACB immediately before the disposition, and

(ii) any disposal costs incurred as a result of the disposition e.g. broker's commissions etc.

In this context, the tax treatment of capital gains/losses will vary according to whether the stock option was acquired prior to or subsequent to January 1,1972 . The treatment under these two alternatives is discussed below.

(i) Option Granted After January 1, 1972:

The tax position under these circumstances is relatively straightforward. The cost of the shares will be the price paid by the employee in exercising his option. Hence, where an employee acquires stock with a FMV of $\$ 50$ and pays $\$ 40$ for the option, the cost of the stock is $\$ 40$. To this figure is added the value of the s.7 benefit i.e. $\$ 10$, thereby giving an ACB of $\$ 50-8.53(2)(j)$. If this stock is disposed of for $\$ 70$ at a disposal cost of $\$ 2$ per share, the "gain" under 8.40 will be equal to $\$ 18$ per share. The taxable capital gain under 8.38 will then be $\$ 9$ per share, this last amount being taxed as income at full rates.

(ii) Option Granted Before January 1, 1972 and Exercised After That Date:

Where an option was granted prior to 1972, but exercised thereafter, a new factor is introduced in the form of V-Day prices. Suppose that an option was granted in 1970 to purchase shares at $\$ 10$. On V-Day the value was $\$ 12$. The option was actually exercised in 1973 when the stock had a FMV of $\$ 15$ and sold in 1974 for $\$ 20$. Then by virtue of s.26(3) I.T.A.R., the ACB of the option is the higher of its original cost and its FMV on V-Day-

10 Id. at 78. 
i.e. $\$ 12$. To this amount is added the deemed benefit under s.7. Any gain on the sale of the stock for $\$ 20$ will be computed in the same manner as in (i) above with one-half being taxable at full rates as a taxable capital gain.

\section{Deemed Disposition of Earliest Stock}

Great caution should be exercised by employees in disposing of their stock acquired prior to January 1, 1972 under an employer stock option plan. Where an employee has acquired stock over a period of years spanning the time both before and after January 1, 1972, and later disposes of some stock for whatever reason, then by virtue of s.26(8)(e) I.T.A.R., the shares acquired before January 1, 1972 are deemed to be sold first. Thus, the unwary employee may be faced with the prospect of an unexpected capital gain, with the resultant tax consequences. An illustration of the above may reveal the tax effects of such a transaction. Suppose an employee has acquired 10,000 shares of stock under an employer stock option plan prior to January 1,1972 , at a cost of $\$ 5$, with FMV on VDay of $\$ 10$. In 1973 he purchases 1000 extra shares at $\$ 15$ with FMV of $\$ 20$ and immediately sells these shares.

Cost of Stock Option
FMV of Stock
Section 7 Benefit
Tax thereon @ 64\% (assuming
$47 \%$ Federal and 36\% Alberta)
Further:

FMV of Stock Proceeds

ACB of Stock

per s.26(8)(e) I.T.A.R.

Taxable Capital Gain

Tax Theron@64\%

Net Proceeds Left

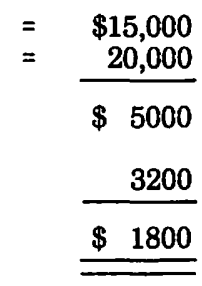

$=\$ 20,000$

10,000

$\$ 10,000$

$\$ 5,000$

3,200

$\$ 1,800$

Hence the gain of $\$ 5000$ in obtaining the stock option has resulted in a tax liability of $\$ 6400$. This illustration shows that the employee should be particularly circumspect in this area. The executive may have avoided this situation by using a s.85 rollover to a corporation before exercising his latest option.

The tax consequences may have been even more severe than in the above example. Suppose, for example, that the FMV of the stock fell to $\$ 10$ and the executive sold. In these circumstances, he could not offset his capital loss here, because the cost is deemed at $\$ 10$. In effect, he loses his capital loss and is out of pocket at the same time.

In addition to the problem cited above, the executive should be particularly careful in timing his disposition for maximum tax advantage. It should be borne in mind that tax deferred is a genuine saving in tax, 
whereas tax prepayment is a distinct disadvantage. The impact of timing is particularly highlighted in a situation where an executive acquires stock on the option plan and later sells the stock at a price midway between the option price and FMV at the date of acquisition. For example, suppose an executive has an option to acquire 10,000 shares at $\$ 20$ per share. He exercises part of his option and acquires 5000 shares when the FMV is $\$ 30$, and then disposes of 3000 shares at $\$ 25$.

Then:

Acquisition of Stock Option FMV at $\$ 30$

Section 7 Benefit

Tax Thereon at $64 \%$

Net Proceeds

Sale of 3000 shares at $\$ 25$

ACB 3000 shares at $\$ 30$

Capital Loss

Allowable Capital Loss

Tax Savings at $64 \%$

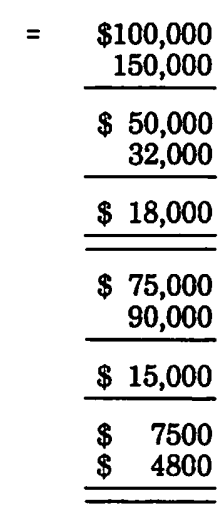

Here the executive realized a gain of $\$ 5 \times 3000=\$ 15,000$, and his immediate tax outlay is $\$ 27,200$. The problem, of course, arises because he is taxed at full income rates on the 8.7 benefit, but may only deduct one-half of his capital loss of $\$ 5$. Such a situation may impose severe financial penalties on an executive's cash flow at any point in time.

\section{Departing Residents}

Finally, one of the major nuisances of the I.T.A. is s.48, which stipulates that any person, ceasing residence in Canada, is deemed to have disposed of some of his property, thereby subjecting unrealized capital gains to taxation. The situation is common enough, e.g. an executive from the U.S. or U.K. takes over the management of a Canadian subsidiary. However, the "departure tax" as it has come to be known, does not apply to stock option benefits. The reason for this is that stock options are not considered to be "capital property" as defined in s.54(b)(ii). Rather, its sale gives rise to ordinary income under s.7(1) and not a capital gain. However, there remains a problem for non-residents, who were formally employed in Canada by virtue of $8.2(3)$ and $s .115(1)$. Thus, by virtue of $8.7(4)$ and s.115(1), the non-resident would be taxed on the benefit. There remains a pragmatic consideration as to who will enforce the tax and how this will be accomplished.

\section{DEFERRED COMPENSATION PLANS}

The fundamental precept of a DCP is to postpone income from one time period to another, thereby effecting a tax saving. If income is deferred, the employer cannot deduct any current charge from his income, but may only deduct when the payment is actually made. The problem with a DCP is that if the employee is not to be taxed immediately, his rights under the DCP cannot and must not vest immediately. If the right does vest immediately, the employee will be taxed, probably on the net present value of future cash inflows. In this regard, great care 
should be directed to the drafting of the agreement, in order to introduce the necessary element of contingency and prevent immediate vesting. This may be achieved by the introduction of three elements:

(i) contingency of continuous employment of the executive until normal retirement age;

(ii) a "no-competition" provision on retirement;

(iii) agreement to provide reasonable consulting services.

The plan may actually go further and provide for DCP payments only upon the discretion of the employer. The danger in this course of action is that the employee's rights are jeopardized.

A DCP may provide for a lump sum payment upon death of the employee, with the payment being directed to the widow. In such a situation, the equivalent of one year's salary or $\$ 10,000$, whichever is the lesser, is exempt from taxation and only the excess is taxed in the widow's hands. Alternatively, the DCP may provide for lump sum payment to be made upon retirement. The advantage of this route is that it provides the employee with greater flexibility, in that he may choose an annuity and defer tax or pay immediately and enjoy the money-8.61. Needless to say, all payments must be reasonable in order to conform with s.67. This last requirement does not usually pose any severe problems.

As an alternative, the company may predicate its compensation on the value of the company's stock, and agree to pay the difference between the value of the company's current price and some future price on some stated number of shares. Thus, a company may notionally assign 1000 shares of its stock to an employee, at a time when the stock is priced at $\$ 40$. Later the stock moves up to $\$ 45$, and the employee is compensated $\$ 5000$. The company may or may not decide to throw in notional dividends. The advantage of such a scheme, often referred to as a Phantom Stock Plan, is that the employer may deduct the charge against income. The corresponding disadvantage is that the employee must include the sum received in his income. A major flaw of this scheme of compensation is that the the proceeds may not be used to purchase an income averaging annuity. This in and of itself may prove fatal to the viability of such plans.

\section{COMPANY CARS}

The use of company cars remains an important vehicle of employee compensation due to the fact that next to a home, the ownership and operation of an automobile remains one of the more expensive living costs of an individual. Where an executive has a marginal rate of tax of $65 \%$, it is reasonable to assume that he will desire an automobile worth $\$ 8000$. If such be the case, and he borrows the necessary funds at a consumer rate of $12 \%$, he must earn approximately $\$ 26,000$ in pre-tax income in order to finance the purchase of this class of automobile, assuming a simple interest charge of $\$ 3000$ per year. Despite the changes introduced in the new Act, the provision of an automobile to an employee may still remain a source of indirect compensation to an executive as the following illustration reveals.

Assume two hypothetical executives, A and B. Executive A drives 12,000 miles per year, 2000 of which is classified as business; Executive B 
drives 18,000 miles per year, 12,000 of which is business. In this situation the costs of operating the vehicle are depicted in Table I, below:

\section{TABLE I}

Cost of Automobile

Average Depreciation for 3 years

Maintenance

Insurance

License

Gas and Oil at $5 థ / \mathrm{mile}$

Total Operating Costs

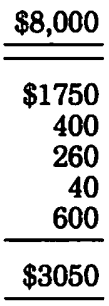

In the above situation, the pre-tax income required to operate the vehicle, and assuming a marginal rate of $65 \%$, will be $\$ 8710$ for Executive $A$ and $\$ 5807$ for Executive B. Given this structure, the taxable benefit to be included in income will depend on whether or not the executives in question reimburse the company for personal use or not. Assuming, as above, that Executive A drives 10,000 personal miles, and Executive B drives 6000 personal miles the following would result under each alternative:

\section{$T A B L E J$}

Standby

Personal use operating costs with depreciation at $254 / \mathrm{mile}$

Without Depreciation Executive A

Executive $B$

\begin{tabular}{cccc} 
Actual Use & Standby & Actual Use & Standby \\
- & $\$ 960$ & - & $\$ 960$ \\
$\$ 2500$ & - & $\$ \overline{430}$ & - \\
\hline
\end{tabular}

Taxable Benefit

without reimbursement

Payment to company for personal use at $5 \% / \mathrm{mile}$

Taxable Benefit with reimbursement

\begin{tabular}{rrrr}
$\$ 2500$ & - & - & $\$ 960$ \\
500 & - & - & 300 \\
\hline$\$ 2000$ & & & $\$ 660$ \\
\hline
\end{tabular}

Table K, reveals the savings to be secured by the use of a company car versus the personal purchase and operation of an automobile.

TABLE K

Executive $A \quad$ Executive $B$

Taxable Benefit

(Table J)

\begin{tabular}{llll}
$\$ 2000$ & $\$ 2500$ & $\$ 660$ & $\$ 960$ \\
\hline \hline$\$ 8710$ & $\$ 8710$ & $\$ 5807$ & $\$ 5807$ \\
\hline
\end{tabular}

Income Required To

Operate Personally

Income Required To Pay Tax

On Taxable Income If

Company Car at $65 \%$

Marginal Rate. 
Income Required to Reimburse Company For Personal Use at $65 \%$ Marginal Rate.

Savings

\begin{tabular}{lcrc}
$\$ 1430$ & - & 850 & - \\
\hline$\$ 7140$ & $\$ 7140$ & $\$ 2565$ & $\$ 2745$ \\
\hline$\$ 1570$ & $\$ 1570$ & $\$ 3242$ & $\$ 3062$ \\
\hline
\end{tabular}

The above illustrations show the substantial savings which accrue to both executives, especially Executive B from the use of a company car, notwithstanding the changes in the new Act in this regard.

\section{AVERAGING}

The reader will have observed that the tenor of this paper has been the concept of tax deferral. To continue along this vein one should not lose sight of the deferral privileges afforded by the concept of averaging in the Act. The averaging provisions may be classified into two broad categories: (1) General Averaging and (2) Forward Averaging. ${ }^{41}$

\section{General Averaging}

The benefits of general averaging are available to every taxpayer and are calculated automatically by the computer in Ottawa. While the computation is automatically performed, a tax advisor may be somewhat remiss in his duty to his client if he failed in advising him of his potential tax liability in advance. However, the advantages that accrue from this form of averaging are minimal as may be seen from the following Table L which depicts the tax treatment of a $\$ 20,000$ stock option benefit where the normal taxable income is $\$ 30,000$.

\section{TABLE L}

\begin{tabular}{|c|c|c|}
\hline & $\begin{array}{c}\text { General } \\
\text { Averaging }\end{array}$ & $\begin{array}{l}\text { Straight } \\
\text { Inclusion }\end{array}$ \\
\hline \multirow[t]{2}{*}{$\begin{array}{l}\text { Normal Taxable Income } \\
\text { Amount of Benefit }\end{array}$} & $\begin{array}{r}\$ 30,000 \\
20,000\end{array}$ & $\begin{array}{r}\$ 30,000 \\
20,000\end{array}$ \\
\hline & $\$ 50,000$ & $\$ 50,000$ \\
\hline Tax Liability & $\$ 10,179$ & $\$ 10,753$ \\
\hline
\end{tabular}

Since general averaging only expands the marginal rates of tax for those years when taxable income is greater than the threshold amount, in many instances there will be no tax savings in comparison with straight inclusion. Under this provision all types of income qualify for averaging when the taxpayer's income reaches $110 \%$ of his previous year's income and $120 \%$ of his previous year's average.

\section{Forward Averaging}

This device is activated by the use of a new creation of the I.T.A. introduced in 1972, entitled an Income Averaging Annuity (IAA). The purpose of forward averaging was stated by the Honourable E. J. Benson as being to spread unusual lump sum receipts in equal amounts over the current and future years, to be accomplished through the purchase of an IAA, obtainable through life insurance companies and a few trust companies. Unlike the general provisions, however, only specified income 
sources are eligible to be averaged. These specified sources are enumerated in $\mathbf{8 . 6 1}$ and in the context of this paper include:

(i) a single payment from a pension plan;

(ii) a single payment received from a DPSP;

(iii) refunds of premiums under RRSP's; and

(iv) employer stock option benefits.

Given that a large amount of income is received in any one year, the taxpayer, if he is a Canadian resident, may purchase an IAA from one of the organizations licensed to issue such contracts. The annuity may be for life with or without a guaranteed term. The maximum guaranteed term is the lesser of 15 years or 85 minus the age of the individual at the time his annuity payments begin. In addition, payments must begin within 10 months after purchase of the annuity, and once the payments commence at least one must be received in each year of the contract. The IAA must be purchased with a single premium, which becomes deductible from current income. However, there is a restriction in that the maximum deduction from current income is the total of the qualified income less an amount equal to an annual payment under the annuity contract. Thus, where a single payment of specified income in the amount of $\$ 24$,000 was received in any year, and a 10 year IAA was purchased providing for $\$ 3146$ each year of the contract, the deduction for the current year would be:

Lump Sum Payment Received

Taxable in Current Year

$$
\begin{array}{r}
\$ 24,000 \\
3,146 \\
20,584
\end{array}
$$

Deductible in Current Year

The advantage of forward averaging versus straight inclusion may be seen in Table $\mathbf{M}$.

\begin{tabular}{lcr} 
& TABLE M & \\
Ordinary Income & $\begin{array}{c}\text { With Forward } \\
\text { Averaging } \\
\text { Taxable Portion of }\end{array}$ & $\begin{array}{c}\text { Straight } \\
\text { Inclusion }\end{array}$ \\
Lump Sum Payment & $\$ 30,000$ & $\$ 30,000$ \\
Total Income & 3146 & 24,000 \\
Exemptions & $\$ 33,146$ & $\$ 54,000$ \\
Taxable Income & 3100 & 3100 \\
\cline { 2 - 3 } Tax & $\$ 30,046$ & $\$ 50,900$ \\
\hline
\end{tabular}

In addition to the advantage to be gained from deferral of tax, there is an added benefit to be derived from investment leverage. This latter effect is due to the fact that both the principal, or a substantial part thereof and the interest may be utilized in the investment process. Thus, an individual who has obtained $\$ 100,000$ of "qualified" receipt and has a $60 \%$ marginal rate of tax, may consider two alternatives. On the one hand, he could pay $60 \%$ tax on his receipt and purchase a $\$ 40,00015$-year mortgage yielding $12 \frac{1}{2} \%$. Alternatively, he may consider purchasing an IAA which would result in $\$ 10,310$ being included in the year of receipt and paying $\$ 89,680$ as a premium to purchase the annuity. In such a situation, he would receive a monthly income of $\$ 484.88$ partially taxable in the first case, and $\$ 860$ fully taxable in the second. The net result after 15 years 
under the two alternatives would be as indicated below, assuming the taxpayer remains in the $60 \%$ bracket:

\begin{tabular}{lcr} 
& Mortgage & \multicolumn{1}{c}{ IAA } \\
Total Payments & $\$ 87,278$ & $\$ 165,120$ \\
Taxable & 47,278 & 165,120 \\
Tax & 28,367 & 99,072 \\
Net Return & 58,911 & 66,048
\end{tabular}

Notwithstanding these advantages of forward averaging, IAA's are not that popular to date. Several reasons may be postulated for this phenomenon:

(i) an IAA requires payment of substantially all funds into the contract and as such is not particularly attractive to the young who may wish to spend the proceeds;

(ii) tax rates have a tendency to creep upwards rather than down, and the assumption of lower marginal rates at some future date may not be valid;

(iii) inflation continues at a rapid pace, contributing further to the tendency for immediate consumption and the flair for hedonism;

(iv) the IAA rates quoted by most insurance companies are not particularly attractive at this time. At any rate, the investment is in a fixed yield form which may not provide the necessary rate of return to all concerned in this particular market.

\section{CONCLUSION}

This paper has examined several alternative methods of compensating key employees. Specifically, these alternatives include RPP's, RRSP's, DPSP's, loans, stock option benefits, company cars and DCP's. That these various indirect media for remuneration provide a viable alternative to the classical form of cash payments should be considered by employers and employees alike. That there is no panacea for executive compensation should be obvious. RPP's, RRSP's and DPSP's share the common characteristic that they provide for retirement income in some future period, thereby reducing the immediate tax burden and eventually minimizing the incidence of taxation in the long run. The precise combination must, of course, be custom structured to suit the individual's and the employer's needs.

At the same time, stock option benefits and DCP's integrate the welfare of the employee with that of his employer. When the employee feels that his reward structure is directly related to the performance of the company, he has the incentive to put forward his utmost. The motivational consequences will depend in large measure on the nature of the company. Where the stock price of the company is influenced over an extended period of time by factors other than performance, such schemes may serve little useful purpose. Where, however, as is usual over any extended period of time, the behaviour of the company's stock is related to performance and such performance is reflected in earnings-per-share etc., the employee is provided with a direct incentive to contribute his best to the welfare of the enterprise.

Finally, when the employee is placed in the fortunate position of reaping a lump sum payment from one of the aforementioned investments, he may well consider further deferment through the medium of forward 
averaging and the purchase of annuity contracts. If taxation, like death is certain, it is equally probable that individuals will seek to escape its ravages by all the legitimate means available in the provisions of the Income Tax Act. While total escape remains unlikely, minimization continues as a distinct and advantageous possibility. 